http://ejournal.ihdn.ac.id

\title{
PRANAYAMA SEBAGAI SAINS SPIRITUAL
}

\author{
Ni Putu Rosa Agustina Maharani \\ Akademisi tinggal di Tabanan \\ Email: Rosaagustina789@gmail.com
}

\begin{abstract}
:
'Pranayama' consists of: Puraka which is entering the breath, Kumbhaka which is holding your breath, and Recaka is exhaling. But from the essence of pranayama is the ability to take and manage prana especially by using breath. In spiritual life, Pranayama's role depends on the individual. They feel that by asking for Protection, Peace and the Light of God they can change their nature and purify their lives as effectively as possible by doing Pranayama. The only breathing exercise that a spiritual candidate needs is to try to breathe pure. Control over the flow of prana in the vital body which calms the mind and limits the thought process, which is an important introduction to spiritual exercises. In the text of yoga sutra patanjalai pranayama is explained in the shadana padha sutra 49 which explains what the meaning of pranyama, sutra 50-51 describes the practice of pranayama, In Yoga Sutra, Patanjali describes pranayama as a process where they can break their subconscious breathing patterns and make long breath, subside, and smooth. The subconscious breathing pattern of some people is not easy and smooth; They tend to be tense, superficial, and erratic. Pranayama can also be practiced through java pranama, pranyama also has many techniques to practice pranyama, spiritual seekers get peace of mind. As long as some breathing techniques are slowed down and the strength of the exhaled air decreases. The well-known breathing techniques teach how to activate, stimulate energy that makes a person feel calm, relaxed, and comfortable. The purpose of pranayama is to reduce the speed of breathing / slow down breathing, Prana will be calm with a slow / slow breathing process. The mind will calm down, When breathing activity decreases, the activity of the mind will decrease, Between mind and prana are the senses.
\end{abstract}

Key words: Pranayama, control and relaxed 


\section{PENDAHULUAN}

Pranayama adalah aspek tradisional yoga. Kata'pranayama' berasal dari bahasa sanskerta:'prana' dan 'ayama'. Awalnya 'prana' mengacu pada "energi kehidupan", tetapi juga mencakup konsep-konsep seperti nafas, angin, kehidupan, vitalitas, energi dan kekuatan. dan Ayama dapat diterjemahkan sebagai peraturan, perluasan atau dimensi. 'Pranayama' sering dikatakan sebagai "kontrol nafas". 'Pranayama' terdiri dari : Puraka yaitu memasukkan nafas, Kumbhaka yaitu menahan nafas, dan Recaka yaitu mengeluarkan nafas. Tetapi dari esensi pranayama adalah kemampuan untuk mengambil dan mengelola prana terutama dengan menggunakan nafas. 'Pranayama' dapat mencapai tingkat energi yang lebih tinggi dalam kehidupan sehari-hari, dan untuk mencapai wawasan diri dan kendali diri yang lebih besar.

Dalam kehidupan spiritual,peran Pranayama bergantung pada individu. Ada banyak yang tidak melakukan latihan pernapasan sebelum meditasi. Sebaliknya mereka memanggil Cahaya dan Kehadiran Tuhan. Mereka merasa bahwa dengan memohon Perlindungan, Perdamaian dan Cahaya Tuhan mereka dapat mengubah sifat mereka dan memurnikan hidup mereka seefektif mungkin dengan melakukan Pranayama Satu-satunya latihan pernapasan yang dibutuhkan calon spiritual adalah mencoba untuk bernafas dengan murni. Saat bernapas, jika ia secara sadar membayangkan dan merasa bahwa ia bernapas dalam Kesempurnaan dari Atas, maka keterbatasan di dalam sistemnya secara otomatis berubah. Saat mereka bernapas secara sadar, prana dalam diri kita memiliki nilai lebih. Tetapi untuk melalui banyak latihan yang kuat sama sekali tidak diperlukan untuk realisasi Tuhan. Jika mereka dapat bernafas secara perlahan dan dalam, dan memiliki perasaan yang berbakti kepada Yang Mahatinggi dan terhadap umat manusia saat bernafas, kita akan dapat memasuki dunia dengan nafas kita yang terlahirkan. Ketika kita menghirup dengan perasaan pengabdian spontan, kita dapat melayani Yang Mahatinggi serta kemanusiaan secara spiritual dan material.
Sebagian besar dari mereka bernafas dengan keliru, hanya menggunakan bagian kecil dari kemampuan paru - paru mereka. Nafas mereka pendek dan akibatnya bahwa tubuh dan otak mereka kekurangan, yang sepenuhnya tidak perlu dengan menganggap persediaan oksigen di udara yang berlimpah semuanya ada di sekitar mereka. Dengan nafas yang pendek kita juga membuat udara terhenti pada daerah paru - paru bagian bawah dan dapat menimbulkan berbagai macam penyakit secara fisik maupun spiritual (sumber: https://www.breatheology.com/pranayamapoweruniverse/https://www.srichinmoylibrary.co $\mathrm{m} /$ bhf-25 diunduh, 25 oktober 2018).

\section{Praktik pranayama dalam teks dan dalam praktik}

Adapun praktik pranayama pada teks yoga sutra patanjali yang dicantumkan dibagian sadhana padha Sutra 50 dan 51 yang berbunyi :

Bahya-abhyantara-sthamba vrttih-desakala-sankhyabhih paridrsto dirghasuksmah

Terjemahan :

( bagian II, sutra 50 )

"(Proses mengurangi kecpatan nafas adalah dengan cara mengatur ) bahya, napas yang keluar (recaka); abhyantara, nafas yang masuk (puraka); dan sthambha, nafas yang ditahan (kumbhaka) yang mesti dilakukan dengan memperhatikan desa atau tempat; kala atau waktu, dan samkhya atau jumlah siklus (putaran nafas). Demikian ( dengan abhyasa, berlatih terus-menerus).

Seseorang dapat merasakan bila nafasnya menjadi makin panjang dan halus."Pada sutra ini ada tiga golongan, (a) yang diluar, (b) didalam, (c) yang tetap dan ketigaanya berkenaan dengan jangka, waktu dan jumlah; dibuat berlangsung waktu panjang atau singkat.
Bahya-abhyantara visaya-aksepi caturthah
( bagian II. Sutra 51)
Terjemahan :
"Pengaturan aliran kehidupan atau pranayama dengan cara diluar atau melampaui penarikan dan penghembusan 
nafas ( serta penahanan nafas ) disebut (proses) keempat"

Ada juga golongan ke-empat, yang terdiri dari pembuangan dan penahanan nafas - keluaran serta pembuangan dan penahanan nafas - masuk. Praktek Pranayama bisa memakai Pranava Japa atau dengan Gayatri Mantram. Bila menggunakan Pranava Japa, pengaturan nafas dilakukan dalam tiga tahapan, yaitu: Menarik Nafas (Puraka), Menahan Nafas (Kumbhaka), Menghembuskan Nafas (Recaka)

1. Ucapkan $A(n g)$ dalam hati saat menarik nafas (Puraka), bayangkanlah Tuhan sebagai Sang Maha Pencipta yang penuh anugerah.

2. Ucapkan, U(ng) dalam hati saat menahan nafas (Antah Kumbhaka), bayangkan Tuhan sebagai Sang Maha Pemelihara yang penuh dengan cinta kasih.

3. Ucapkan M(ang) dalam hati saat menghembuskan nafas (Recaka), bayangkan Tuhan sebagai Sang Maha Suci, pelebur segala kekotoran batin dan dosa-dosa.

Bila menggunakan Gayatri Mantram, pengaturan nafas dilakukan dalam empat tahapan, yaitu:

1. Menarik Nafas (Puraka), sambil mengucapkan OM Bhur Bhvah Svah di dalam hati

2. Menahan Nafas (Antah Kumbhaka), sambil mengucapkan Tat Savitur vareniyam di dalam hati.

3. Menghembuskan Nafas (Recaka), sambil mengucapkan Bhargo devasya dimahi di dalam hati.

4. Menahan Nafas (BahihKumbhaka), sambil mengucapkan Dhiyoyonah pracodayat di dalam hati.

Dengan mempraktekkan pengaturan nafas ini seorang sadhaka bisa memperoleh umur panjang. Seorang lelaki sehat bernafas 14 sampai 16 kali dalam semenit. Pengurangan frekuensi nafas melalui latihan pranayama, dapat meningkatkan ketahanan paru-paru. Frekuensi nafas juga ada kaitannya dengan kehidupan spiritual. Semakin sedikit nafsu keinginan seseorang, semakin rendah frekuensi nafasnya, demikian juga sebaliknya. Bagi yang mempraktekkan japa, meditasi dan mempelajari kitab-kitab spiritual-religius/kitabkitab suci, akan mempunyai frekuensi nafas yang lebih rendah dan mempunyai konsentrasi yang lebih baik. Semakin rendah frekuensi nafas seseorang, juga berarti semakin meningkat konsentrasinya dan lebih tenteram hidupnya. Jadi, pengaturan nafas bukan saja terkait dengan kesehatan dan umur seseorang, namun terbukti memang memungkinkan konservasi serta pengaturan daya-vital yang baik hingga amat kondusif dalam pengembangan batin. (http://www.hindu-dharma.org/2012/08/praktekpranayama/diunduh 8 november 2018).

Sains mungkin belum mengeksplorasi pikiran yang mendalam, tetapi banyak orang melakukannya. Mereka adalah para mistikus, petapa, dukun dan pakar spiritual di setiap kebudayaan. Mereka ini telah menggunakan praktek-praktek seperti Pranayama untuk menggali apa yang ada dibalik pernafasan yang teratur. Mereka telah mengamati teknik pernafasan yang lama makin diperlambat dan kekuatan udara yang dihembuskan berkurang. Dan mereka telah melihat di balik itu, pada sumber pengalaman mereka, esensi kesadaran mereka sendiri. Di sana mereka telah menemukan hubungan dasar yang mendalam dengan semua makhluk. Ilmu pengetahuan Barat biasanya tidak memberikan banyak perhatian untuk pendekatan subjektif tersebut. Mereka tidak menganggapnya "ilmiah". Para ilmuwan terpaku dengan kebenaran obyektif, dengan fakta-fakta yang dapat diverifikasi yang tidak tergantung pada kondisi pikiran seseorang. Mereka mencari efek yang dapat diukur, bukan perubahan subjektif internal.

\section{PEMBAHASAN}

\subsection{Prinsip - Prinsip Sains Dalam Pranayama.}

Pernapasan klavikula (tulang selangka) adalah pernafasan yang paling pendek dan paling buruk. Bahu dan tulang selangka diangkat, sementara perut berkontraksi selama inhalasi. Maksimum usaha dialakukan, namun hanya sejumlah minimum udara diperoleh. Pernapasan dada (thoraks) dilakukan 
dengan meregangkan otot-otot tulang rusuk untuk memperluas rongga dada. Walau lebih baik daripada pernafasan klavikula, namun pernafasan bukan pernafasan yang lengkap. Pernapasan perut (abdominal) adalah pernafasan yang terbaik, karena mampu membawa udara ke bagian terbawah dan terbesar dari paru-paru. Pernapasan dilakukan dengan lambat dan dalam, dan dengan memfungsikan diafragma.Sebenarnya, ketiga macam pernafasan di atas bukanlah pernafasan yang lengkap. Pernafasan yoga penuh (dirgha-swasam) menggabungkan ketiganya.

Hal terpenting tentang pernapasan yang benar adalah prāna atau energi vital. Teknik-teknik pernafasan yang sudah banyak dikenal, mengajarkan cara mengaktifkan, merangsang energi yang membuat seseorang merasa tenang, santai, dan nyaman. Dalam yoga, energi yang seseorang hirup, dan yang terasa menyegarkan dalam setiap tarikan nafas ini disebut prāna. Prāna adalah energi yang bersifat universal di alam - prāna ada di manamana. Seporsi prāna juga ada dalam tubuh manusia. Prāna mengalir pada lapisan superfisial (dekat dengan permukaan) untuk menjaga tubuh dan organ-organnya.

Pencari spiritual mendapat ketenangan pikiran. Selama beberapa teknik penrnafasan makin lama makin diperlambat dan kekuatan udara yang dihembuskan berkurang. Pengendalian atas aliran prana dalam tubuh vital yang menenangkan pikiran dan membatasi proses berpikir, yaitu suatu pendahuluan yang penting untuk latihan - latihan spiritual. Lubang hidung kiri sangat erat hubungannya dengan ida nadi ketika aliran udara pada kedua lubang hidung sama. Kemudian prana mulai mengalir di sepanjang nadi yang paling penting dalam tubuh vital, yaitu susumna dalam keadaan ini konsentrasi yang dalam menjadi mungkin, yang memungkinkan seseorang mencapai keadaan meditasi yang tinggi, dalam " The Science Of Pranayama" Svami Sivananda mengatakan : “ Ada suatu hubungan yang erat antara nafas, arus syaraf, dan pengaturan prana dari dalam atau kekuatan - keluatan vital. Prana menjadi terlihat pada bidang fisik sebagai gerakan dan tindakan, pada bidang mental sebagai pikiran. Pranayama merupakan cara dimana seorang yogi mencoba menyadari dalam tubuhnya yang kecil seluruh kehidupan kosmos, dan mencoba mencapai kesempurnaandengan mendapatkan seluruh kekuatan alam semesta".

\subsection{Pranayama dan Kebermanfaatan Dalam Hidup.}

Prana berarti nafas, energi dan ayama artinya pajang atau memanjang. Pranayama adalah latihan pernafasan dalam yoga, (Wirawan, :77). Prana adalah kekuatan vital yang bertanggung jawab atas semua fungsi tubuh dan pikiran. Dengan demikian secara umum dipahami sebagai pengaturan nafas untuk mengendalikan tubuh dan pikiran.Pranayama mempunyai tiga fase penting yaitu:

Puraka: pelan, terkontrol, penarikan nafas kedalam secara penuh.

Recaka: pelan, terkontrol dan penghembusan nafas keluar secara penuh.

Kumbhaka: penahanan nafas.

Didalam pranayama memiliki berbagai macam jenis dan manfaat yang sangat banyak banyak dalam hidup, pada Teks Hatha Yoga Pradipika (II: 48-70) mejelaskan delapan jenis pranayama, yaitu suryabhedana, ujjayi, sitkari, sitali, bhastrika, bhramari, murccha dan plavini. Dengan melakukan latihan pernafasan atau pranayama dengan teratur seseorang membersikan diri dari dalam sehingga pikirannya akan menjadi tenang.

Kemudian dalam I Made Aripta Wibawa dalam bukunya "Pengetahuan Dan Pengendalian Prana (Pranayama) menjelaskan tiga jenis pranayama yaitu adhama, madyama dan uttama (yang rendah, sedang, atau yang paling tinggi). Adhama pranayama terdiri dari 12 matra, madhyama terdiri dari 24 matra dan uttama menyita waktu 32 matra. Ini untuk melakukan puraka. Rasio antara puraka (penarikan nafas), kumbhaka (proses penahanan nafas), dan recaka yaitu proses pengeluaran nafas, adalah 1;4;2. Apabila merekamenarik nafas selam 12 matra andaharus melakukan kumbhaka 48 matra. Kemudian waktu untuk recaka menjadi 24 matra.

Kumbhaka merupakan penyimpanan atau penahanan nafas, yang dapat meningkatkan periode kehidupan. Ia memperbesar kekuatan spiritual 
bathin, keberanian dan vitalitas. Para Yogi dengan penarikan nafas pada brahmarandhradi puncak kepala dan dengan menjaganya tetap disana, mampu mengalahkan dewa kematian Yama, dan dapat menaklukan kematian. (Wibawa, 1998: 59).

Salah satu alasan utama teknik pranayama yang mendorong napas panjang dan mulus sangat bermanfaat adalah karena bila dipraktekkan dengan benar, mereka dapat mendukung sistem saraf parasimpatis dan mengaktifkan apa yang biasa dikenal sebagai "respon relaksasi. , "mengurangi stres dan pengaruhnya terhadap tubuh dan pikiran seseorang. Akibatnya, ketahanan seseorang dalam menghadapi tantangan atau kesengsaraan meningkat, dan pikiran seseorang menjadi lebih fokus dan tenang.

Teknik Dan Manfaat Pranayama

Sebelum melakukan praktek pranayama ada baiknya mengerti teknik bandha yaitu menahann dan mengencangkan. Sebab seseorang yang tidak mengerti tiga jenis bandha (jalandhara bandha, uddiyana bandha, mula bandha), tidak akan mendapatkan keberhasilan dalam pranayama. Adapun ketiga bandha tersebut dapat dijelaskan sebagai berikut:

1. Jalandhara Bandha adalah teknik menarik nafas kemudian tahan nafas dengan menunduk kepala kebawah menutup saluran tenggorokan.

2. Uddiyana Bandha, adalah teknik menarik perut kedalam saat menarik nafas, kemudian menahan nafas.

3. Mula Bandha adalah teknik menutup otot anus dan organ reproduksi.

4. Dalam proses pranayama terdapat beberapa teknik-teknik yang dapat dilakukan, ada pun diantaranya adalah sebagai berikut:

\section{Abhyantar Pranayama}

Abhyantar Pranayama dapat dilakukan dengan posisi vajrasana posisi kedua tangan diatas paha. Setelah itu Tarik nafas melalui kedua hidung sambal angkat kepal keatas, kemudian tahan nafas di rongga dada beberapa waktu sesuai kemampuan kemudian hembuskan. Pada saat menahan nafas kepala menundu. Ulangi pelaksanaan ini sebanyak 3 kali dan lakukan tiga bandha.

Adapun manfaat dari pranayama ini yaitu menyembuhkan sesak nafas, takut, nafas pendek, dan membangkitkan kepercayaan diri.

2. Bhayantar Pranayama

Bhayantar Pranayama dapat dilakukan dengan sikap vajrasana kedua tangan diatas paha. Setelah itu, Tarik nafas melalui kedua hidung. Hembuskan nafas sampai habis, lalu tahan sesuai kemampuan. Lakukan sebanyak 3 kali. Teknik ini, bermanfaat meningkatkan kekebalan tubuh, tubuh menjadi lebih langsing, wajah bercahaya. Meningkatkan kesuburan oragan reproduksi pria dan wanita. Bhayantar Pranayama sangat bagus bagi brahmacari. (cat: jangan melakukan pranayama ini apabila melakukan hubungan suami istri pada malam harinya)

3. Surya Bhedi Pranayama

Selanjutnya adalah teknik Surya Bhedi Pranayama. Pranayama ini dapat dilakukan dengan sikap vajrasana kedua tangan diatas paha. Ada dua tahap yang dapat dilakukan dalam pranayama ini. Yang pertama tutup hidung kanan dengan ibu jari tangan kanan kemudian Tarik nafas melalui hidung kiri, tahan beberapa waktu sesuai kemampuan hembuskan melalui hidung kanan dengan menutup hidung kiri.

Kedua yakni tutup hidung kiri dengan itu jaringan tangan kiri kemudian Tarik nafas melalui hidung kanan. Tahann sesuai kemampuan hembuskan melalui hidung kiri dan tutup lubang hidung kanan. Ulangi kedua langka-langka diatas sebanyak 3 kali.

Manfaat dari Surya Bhedi Pranayama adalah menyeimbangkan kedua energy dalam tubuh. Energy matahari masuk melalui hidung kanan dan energy bulan masuk melalui hidung kiri. Selain itu teknik ini juga dapat menghilangkan pilek, penyakit kelenjar tenggorokan, sesak nafas dan menenangkan pikiran.

\section{Bhastrika Pranayama}

Bhastrika Pranayama dapat dilakukan dengan sikap vajrasana. Ada tiga tahapan yang harus dilakukan dalam Bhastrika Pranayama, yakni pelan, menengah dan cepat. Pertama-tama kepalkan kedua tangan letakan sejajar bahu, kemudian luruskan 
keatas dan Tarik kembali kebawah dengan mengucapkan So-Ham mengikuti gerakan tangan sebanyak 3 kali. Saat mengucapkan So tangan keatas dan pada saat mengucapkan Ham tangan kebawah. Mula Bandra tetap dilakukan seperti yang telah dijelaskan diatas.

Kemudian yang kedua posisi yang sama seperti diatas ucapan So-Ham diganti dengan nafas masuk dan keluar mengikuti irama gerakan tangan. Bhastrika Pranayama perlu dilakukan dalam 3 tahap masing-masing 1 menit, pada tahap satu dilakukan dengan pelan, kedua lebih cepat dan ketiga paling cepat.

Adapun manfaat dari Bhastrika Pranayama adalah menghilangkan stress, marah, tidak punya tenaga, tidak bisa mengambil keputusan, selalu merasa lemah, tidak konsentrasi, pikiran kacau, suka menjelek-jelekan dan mengkritik orang lain. Bhastrika Pranayama dianggap sebagai rajanya pranayama. (cat: untuk yang mengalami sesak nafas, jantung tidak sehat dan tekaan darah tinggi sebaiknya melakukan tahap awal atau pelan)

\section{Anulom Vilom Pranayama}

Anulom Vilom Pranayama dapat dilakukan dengan menutup hidung kanan dengan ibu jari kanan, kemudian Tarik nafas melalui hidung kiri, tampa menahan nafas kemudian hembuskan melalui hidung kanan denga menutup hidung kiri. Posisi badan tetap mengambil sikap vajrasan. Lakukan secara bergantian selama 1-3 menit setiap tahapannya. Anulom Vilom Pranayama dapat menyeimbangkan tekanan darah, baik tinggi atau rendah, melancarkan peredaran darah, susah tidur, paru-paru basah, cemas, takut, sakit kepala, migren dan vertigo. (Mula Bandha tetap dilakukan)

\section{Kapalbhati Pranayama}

Tetap mengambil sikap yang sama diatas, Tarik perut kedalam dengan bantuan tangan sambal menghembuskann nafas melalui hidung dengan bersuara. Tetapi pada saat menarik nafas jangan bersuara, Tarik dengan lembut. Lakukan Kapalbhati Pranayama selama 1 menit. (cat; Kapalbhati Pranayama perlu pendampingan seorang guru karena memiliki efek samping jika salah dilakukan)

Manfaat dari Kapalbhati Pranayama adalah mengecilkan perut atau mengurangi kegemukan, dalam tiga bulan seseorang dapat menurunkan berat badan 1-3 kg bila dilakukan dengan cara yang benar. Selain itu, pranayama ini juga dapat membuat wajah bercahaya dan tenang. (Mula Bandha tetap dilakukan). Perkecualian : tidak untuk wanita hamil dan orang yang pernah terserang stroke dan jantung.

\section{Bhramari Pranayama}

Posisi masih sama, tutuplah kedua telinga dengan kedua ibu jari, kemudian Tarik nafas dalamdalam melalui kedua lubang hidung, hembuskan nafas dengan lembut sambal mengeluarkan suara mendengung seperti seekor lebah secara secara berturut-turut 3-6 kali. Kemudian pada saat berhenti bersuara tetap tutup telinga dan dengarkan suara yang ada di dalam badan. Lakukan selama 3 kali dengan tetap memperhatikan Mula Bandha.

Bhramari Pranayama ini bermanfaat untuk menenangkan pikiran pada saat ada masalah mendadak. Pranayama ini juga membuat wajah mejadi bercahaya, pikiran menjadi kuat, jauh dari penyakit telinga. Bahkan para yogi yang melakukan Bhramari Pranayama akan mengetahui Anahatnada (suara bathin) dan mengetahui kematiannya.

Pranayama mengurangi racun dan limbah dari dalam tubuh, serta melindungi tubuh dari penularan penyakit.Pranayama membantu fungsi pencernaan. Dengan cara bernafas yang tepat, metabolisme dan kondisi kesehatan akan membaik.Pranayama mengembangkan konsentrasi dan pemusatan pikiran (fokus), juga memerangi stress dan menyantaikan tubuh. Mengendalikan pernafasan juga memberi ketenangan dan kedamaian pikir.Pranayama membawa kepada pengendalian diri yang lebih baik. Dengan konsentrasi, kita lebih lebih mampu mengatasi emosi dan reaksi. Pikiran dapat berfungsi lebih jernih, menghindari perselisihan dan keputusan yang salah. Selain itu, pengendalian diri juga meliputi pengendalian atas tubuh fisik.Pranayama mengantar kepada perjalanan spiritual melalui tubuh dan pikir santai. Ketika dilakukan dengan benar, Pranayama memiliki nilai kuratif yang besar. Cegukan, batuk, asma, dan nyeri di kepala, telinga, dan mata, adalah beberapa gejala yang secara efektif bisa diatasi melalui pengendalian pernafasan.Pranyama juga disebutkan 
dapat mengurangi air-besar, urin, dan dahak.Lebih jauh, pranayama memperkuat dan menyegarkan tubuh, pikir, dan memiliki efek meremajakan.Yoga mengajarkan cara menggunakan paru-paru dalam kapasitas maksimumnya dan cara mengendalikan nafas. Pernapasan yang tepat harus dalam, lambat, dan ritmis (berirama). Pernafasan seperti ini akan meningkatkan vitalitas dan kejernihan mental.

\subsection{Praktik Pranayama Sebagai Gaya Hidup.}

Untuk hidup seseorangmemerlukan energy yang cukup, ada berbagai sumber energy yang bisa seseorang dapatkan untuk menjaga kelangsungan hidup. Sumber energy tersebut adalah: makanan, makanan mengandung prana, untuk mendapatkan manfaat yang optimal dari prana dalam makanan maka perlu diketahui cara memasak makanan sehingga energy prananya tidak berkurang atau bahkan lenyap.

Sumber kedua dari energy prana adalah melalui nafas. Energi prana ini mesti disebarkan keseluruh tubuh, sehingga setiap bagian dari tubuh dari yang terkecil hingga terbesar mendapatkan bagiannya dengan rata. Untuk itu diperlukan sistem yang berjalan secara harmonis. Aktivitas untuk mengharmoniskan sistem pernafasan ini dengan melakukan praktek pranayama yang cukup, sehingga energy prana bisa menyebar secara merata disebut dengan Pranayama..

Tujuan melakukan pranayama adalah untuk mengurangi kecepatan bernafas/melambatkan nafas, Prana akan menjadi tenang dengan proses nafas yang slow/pelan. Pikiran akan menjadi tenang, Ketika aktifitas nafas semakin berkurang maka aktifitas pikiranpun akan menurun, Antara pikiran dan prana adalah indra-indra. Titik temu antara pikiran dan prana inilah organ-organ indriya, organorgan indriya akan aktip bilamana pikiran atu prana aktif.Pikiran bisa bekerja dengan adanya energy prana, membatasi aktivitas nafas, mengurangi energi sehingga mengurangi gerak pikiran, pikiran lebih mudah untuk dikonsentrasikan.Seperti mandi diperlukan untuk membersihkan tubuh, demikian juga Pranayama diperlukan untuk membersihkan pikiran.

Bernafas juga selain menyerap energi juga mengeluarkan racun-racun dalam tubuh. Kalo diperhatikan sebenarnya pembuangan racun terbesar dari dalam tubuh seseorang dilakukan oleh nafas itu. Karena bernafas adalah proses yang berkelanjut tidak pernah berhenti selama kita masih hidup.Bernafas terdiri dari beberapa aktivitas: menarik nafas (menarik energi dari alam samesta ini, tubuh energize ), kemudian menahan nafas (menyerap energi dan mengedarkannya keseluruh tubuh), menghembuskan nafas (mengeluarkan energi negative atau racun-racun dalam tubuh, tubuh relax), kemudian menahan nafas (ada jeda sebelum menarik nafas lagi setelah menghembuskan nafas).Ada banyak teknik pranayama, baik dari kelompok-kelompok yoga, kelompok-kelompok beladiri, kelompok-kelompok kepercayaan kepada Tuhan Yang Maha Esa. Baik yang berasal dari dalam negeri maupun yang berasal dari luar negeri.

Ketika seseorang melakukan pranayama, pikiran menjadi lebih tenang sehingga mudah untuk diarahkan atau dikonsentrasikan pada objek-objek tertentu misalnya: belajar, bekerja. Demikian pula indra-indra bisa bekerja karena adanya energi prana ini. Dengan mengendalikan energi prana dengan baik maka seseorang bisa mengendalikan aktivitas indra-indra dalam tubuh dan juga aktivitas pikiran sehingga mampu mengoptimalisasikan potensi diri untuk meraih cita dan goal-goal dalam hidup ini.Melakukan pranayama selain membersihkan racun dalam tubuh, juga menjaga vitalitas tubuh, juga mampu membersihkan pikiran, mengurangi aktivitas buruk pikiran, mampu meningkatkan pengendalian diri. oleh karenanya buatlah Pranayama ini sebagai bagian dari hidup mereka.

Dalam Yoga Sutra, Patanjali menggambarkan pranayama sebagai proses dimana mereka dapat mematahkan pola pernapasan bawah sadar mereka dan membuat nafas panjang, mereda, dan halus. Pola pernafasan bawah sadar sebagian orang tidak mudah dan mulus; Mereka cenderung tegang, dangkal, dan tidak menentu. Saat mereka takut atau mendengar kabar buruk, mereka sering terkesima menghirup dan kemudian menahan nafas. Pola pernapasan ini dapat mengaktifkan sistem saraf simpatik (sering disebut sebagai "fight or flight 
response").

Delapan anggota badan yoga yang digariskan dalam Yoga Sutra adalah jalan untuk membantu Merekamencapai keadaan Yoga, atau konsentrasi yang terfokus. Tapi konsentrasi fokus ini bukanlah tujuan akhir. Seperti yang dikatakan Patanjali, akibat dari mencapai keadaan perhatian ini adalah Mereka mengalami persepsi yang lebih jelas dan hubungan yang lebih besar dengan Diri sejati mereka.Bila Mereka terhubung dengan Diri sejati mereka, menjadi lebih mudah untuk melihat apa yang bukan Diri sejati Mereka- pikiran, tubuh, pikiran, perasaan, pekerjaan, dan pada dasarnya semua keadaan yang berubah di sekitar mereka. Ketajaman ini memungkinkan Mereka bertindak dari tempat Diri Sendiri, dan ketika Mereka melakukan itu, Mereka mengalami sedikit penderitaan.

Pranayama adalah alat penting untuk membawa Merekapada konsentrasi yang lebih terfokus ini, yang membawa Merekapada persepsi yang lebih jelas, hubungan yang lebih baik dengan Diri, dan pada akhirnya merupakan kehidupan yang lebih bahagia. Dalam Yoga Sutra 2.52, Patanjali menulis, "Akibatnya (dari pranayama), penutup yang menghalangi cahaya batin mereka berkurang." Dengan kata lain, melalui praktik pranayama, Merekadapat mengurangi semua gangguan mental kegelisahan, gangguan, dan keraguan diri - yang mencegah Mereka terhubung dengan cahaya batin Mereka sendiri, Diri sejati mereka. Dengan cara ini, pranayama bisa memiliki efek mendalam pada hidup Anda.

\section{SIMPULAN}

Pranayama adalah alat penting untuk membawa Mereka pada konsentrasi yang lebih terfokus ini, yang membawa Mereka pada persepsi yang lebih jelas, hubungan yang lebih baik dengan Diri, dan pada akhirnya merupakan kehidupan yang lebih bahagia. 'Pranayama'terdiri dari : Puraka yaitu memasukkan nafas, Kumbhaka yaitu menahan nafas, dan Recaka yaitu mengeluarkan nafas. Tetapi dari esensi pranayama adalah kemampuan untuk mengambil dan mengelola prana terutama dengan menggunakan nafas. Dalam kehidupan spiritual, peran Pranayama bergantung pada individu. Mereka merasa bahwa dengan memohon perlindungan, perdamaian dan cahaya Tuhan mereka dapat mengubah sifat mereka dan memurnikan hidup mereka seefektif mungkin dengan melakukan Pranayama Satu-satunya latihan pernapasan yang dibutuhkan calon spiritual adalah mencoba untuk bernafas dengan murni.

Pengendalian atas aliran prana dalam tubuh vital yang menenangkan pikiran dan membatasi proses berpikir, yaitu suatu pendahuluan yang penting untuk latihan - latihan spiritual. Didalam teks yoga sutra patanjalai dijelaskan pranayama itu dibagian shadana padha sutra 49 yang menjelaskan tentang apa pengertian dari pranyama, sutra 50-51 menjelaskan tentang praktek pranayama, pranayama juga bisa dipraktetkan melalu pranaya java, pranyama juga memiliki banyak teknik mempraktekan pranyama, Pencari spiritual mendapat ketenangan pikiran. Selama beberapa teknik penrnafasan makin lama makin diperlambat dan kekuatan udara yang dihembuskan berkurang. Teknik-teknik pernafasan yang sudah banyak dikenal, mengajarkan cara mengaktifkan, merangsang energi yang membuat seseorang merasa tenang, santai, dan nyaman.Tujuan melakukan pranayama adalah untuk mengurangi kecepatan bernafas/melambatkan nafas, Prana akan menjadi tenang dengan proses nafas yang slow/pelan. Pikiran akan menjadi tenang, Ketika aktifitas nafas semakin berkurang maka aktifitas pikiranpun akan menurun, Antara pikiran dan prana adalah indra-indra.

\section{DAFTAR PUSTAKA}

Krishna, Anand. 2015. Yoga Sutra Patanjali Bagi Orang Modern. Jakarta : PT. Gramedia Pustaka Utama.

Saraswati, Swami Satya Prakas. Patanjali Raja Yoga. Surabaya : Paramitha.

Sarasvati, Svami Satyananda. 2002. Asana, Pranayama, Mudra dan Bandha. Surabaya: Paramitha.

Swatmarama, Yogi. The Hatta Yoga Pradipika.

Sari, Ni Wayan. 2013. Pranayama. 
Wirawan, Made. Modul Yoga, Sekolah Tinggi Agama Hindu Dharma Nusantara. Jakarta.

Internet

Sumber:https://www.breatheology.com/pranayamapoweruniverse/www.srichinmoylibrary.com/ bhf-25diunduh, 25 oktober 2018

sumber:http://www.hindudharma.org/2012/08/praktek-

pranayama/diunduh 8 november 2018 